\title{
Library and Information Science Education: Panacea to Restiveness and Roadmap to National Development
}

\author{
Joy C. Onyenachi' ${ }^{1}$ Edward C. Amadi \\ ${ }^{1}$ Michael Okpara University of Agriculture, Umudike, Nigeria \\ ${ }^{2}$ Collection Development Department, Michael Okpara University of Agriculture, Umudike, Nigeria \\ Email: Onyenachijoy@gmail.com, edwardamadi50@gmail.com
}

How to cite this paper: Onyenachi, J.C. and Amadi, E.C. (2018) Library and Information Science Education: Panacea to Restiveness and Roadmap to National Development. Open Access Library Journal, 5: e3963.

https://doi.org/10.4236/oalib.1103963

Received: September 23, 2017

Accepted: April 24, 2018

Published: April 27, 2018

Copyright $\odot 2018$ by authors and Open Access Library Inc.

This work is licensed under the Creative Commons Attribution International License (CC BY 4.0).

http://creativecommons.org/licenses/by/4.0/

\begin{abstract}
Education provides people with basic knowledge, skill and attitude. These would help to improve the quality of life through increased capabilities, assets and activities. Every education is relevant in a particular nation/society/community. This implies that education should be indigenous. Where education does not impact its environment, the society will be plagued with restiveness, militancy, corruption, religious crises, insecurity, unemployment and recession. Nigeria National policy on education advocates self-reliance. Self-reliance means one doing things for one's self rather than depending on having things done for one. It does not mean that individuals do not need assistance. It simply means that the assistance required is to ensure that it places one in a position of better care for one's self. Self-reliance makes one have the ability and capacity to maximize one's effort to earn sustainable living. Self-reliance makes one to have problem-solving ability. Unnecessary or over dependence dulls character of an individual and creates social dysfunctions. Library and information science, a discipline of multi relevance builds the professionals to be self-reliant, which impacts positively in the society. Hence the paper proffers how Library and Information Science education stands as panacea to the restiveness in Nigeria.
\end{abstract}

\section{Subject Areas}

Library, Intelligence and Philology

\section{Keywords}

Library and Information Science, Education, Panacea, Restiveness, National 
Development

\section{Introduction}

Library and Information Science education is a discipline whose core value is information acquisition, processing, preservation and dissemination of the information to meet information need of the citizens for self development and the development of the society. Information/knowledge disseminated embraces all areas of life's need, hence proffering solutions to myriad of issues and problems confronting humanity to which restiveness is among. Human discoveries, innovations, inventions, creativities, research outcome are disseminated as information/knowledge. Information/knowledge is power that emancipates the ignorance and makes him valuable individual to himself and the community where he belongs. Education as defined by English dictionary is the process or art of imparting knowledge, skill and judgment. Library and Information Science therefore is branch of learning (discipline) that fulfills the aim of education. The knowledge, skill and judgment a learner acquires when positively applied should emancipate individuals from restiveness. Mobilization, consultation, orientation, creating awareness as well as formal education through library and information science greatly transfer and impact what to do, when to do and how to do to get it right without resorting to restiveness and other vices.

Restiveness in Nigeria is as a result of favoring a group over another. Nigeria became a nation in 1914 as a result of amalgamation (a nation more than 100 years in age and since 1960 of its independence more than 50 years in age), some parts still formally accept to be educationally disadvantaged and so through federal character, are favored in tertiary institution admission, federal employment and appointments. Others marginalized through agitation demand for their rights. Restiveness is a serious menace in any society. English dictionary defines restive as: resistant of control; stubborn. Library and Information Science education whose essence is information/knowledge delivery to meet needs is indispensable in proffering solution to restiveness. Where restiveness is, the world of work is in jeopardy, and citizen's agitations are many. Agitations in Nigeria comprise: cry over marginalization; resource control based on crude; resource control based on land use decree; who holds the oil blocks (for personal enrichment); crude pipe vandalism; illegal refineries; non productivity of legal refineries; focus on crude to the neglect of other wealth derivable from natural resources; federal character: favoring a group over another in the guise of educationally disadvantaged states.

\section{Militancy in the Niger delta example of restiveness in Nigeria}

Militant means aggressive or combative, fighting or warlike hence militancy is using force or strong pressure on to achieve an aim or aims. The complex events that have influenced the emergence and rise of militancy in Niger Delta are the political economy of oil and its interaction with the historic modalities of inequality in post-colonial Nigeria. The extraction of oil which takes place in the 
Niger Delta accounts up to $75 \%$ of natural oil production in Nigeria. Yet there is utter neglect and lack of developmental benefits to the people who suffer the most consequences of oil extraction (Cawthra, 2011 [1]). The Niger Delta has seen soaring rates of poverty and severe environmental degradation, public health crises, mass displacement loss of traditional means of livelihood, high unemployment and dissatisfaction by the youth (Jike 2010 [2]). The mass destitution seen and experienced in Niger Delta, the lack of developmental gains from oil extraction and community consciousness of clear inequality in the distribution of wealth that accrue from the oil, form the fundamentals of grievance that lead to militancy and restiveness in the Niger Delta region (Idumidia and Ite 2006 [3]).

Kachikwu [4] (2017), points out that "the Niger Delta issue is an old problem which has defied attempt by successive government administration to solve". He agrees that "if you have peace you have investment. If you don't have peace you cannot have investment." Kachikwu notes that "at the heart of militancy is economics. If you create the business you will create the jobs, you create an appreciation of the environment and take people away from core militancy". Kachikwu reports that the Federal Government intends to target specific investment in the following areas:

One specialist school per state;

One specialist hospital per state;

One specialist skill center per state.

The essence is to pull people away from militancy, put them back into school, and put them back into areas where they can have the kind of facilities that will make them proud of their areas.

Among the 20 point plan for resolving the challenges of militancy tin the Niger Delta is "militancy to education initiative." The key focus will be move children from militancy to education. Federal Government will provide incentives for school. The Federal Government's school feeding programme will be introduced. The Federal Government will create additional scholarship opportunities. Parastatals such as Petroleum Trust Development Fund (PTDF) will be expanding scholarship schemes to some of these communities alongside oil companies so people will have an incentive to go back to school instead of engaging in criminal activities (Kachikwu 2017).

\section{Nigeria national policy on education application imperative in addressing restiveness}

Nigerian education must prove its policy and constitution applicability for it to serve as rescue agent. Federal republic of Nigeria [5] has policy on education (NPE) from 1977 till date the $6^{\text {th }}$ edition is published 2013 if applied the restiveness that has persisted should have been overcome. Nigerian is frost with restiveness and agitations as pointed out earlier, the answer to the simple question whether education in Nigeria is working or not would draw a "no". It is imperative on Nigeria at this time to examine the vision, mission and purpose of her 
education in order to direct the minds of teachers and learners to Nigerian needs.

In the Policy Section 1: philosophy and goals of education in Nigeria, in sub section (2) point out the Philosophy of the nation's education thus:

1) Live in unity and harmony as one indivisible, indissoluble democratic and sovereign nation founded on the principles of freedom, equality and justice; and

2) Promote inter-African solidarity and world peace through understanding.

In Nigeria where restiveness is the current canker worm the achievement of the philosophy of the nation's education is in doubt because unity is difficult.

1) It is worthy of note that section 1 of the NPE subsection 3 states that "Nigeria's philosophy of education is based on the following set of beliefs.

a) Education is an instrument for national development and social change;

b) Education is vital for the promotion of a progressive and united Nigeria;

c) Education maximizes the creative potentials and skills of the individual for self-fulfillment and general development of the society etc.

If education which is believed to foster National development and social change, ensure progressive and united Nigeria as well as equip citizens for self-fulfillment and general development of the society is achieving her belief, Nigeria will not be infested with restiveness.

Subsection 6 of the section 1 of NPE presents the goals of education in Nigeria as:

a) Development of the individual into a morally sound, patriotic and effective citizens;

b) Total integration of the individual into the immediate community, the Nigerian society and the world;

c) Inculcation of national consciousness, values and national unity, etc.

From the goals, the educated citizens of Nigeria should be morally sound, patriotic, integrate into the immediate community, the Nigerian society and the world as well as have national consciousness, values and national unity.

Where these are lacking, development cannot take place. This should answer why Nigeria for 104 years as a nation and 58 years of independence is still a developing nation. Restiveness from decade to decade has been the bane of Nigeria.

Subsection 7 (d) of the specific goals of education in Nigeria states that the goals should "ensure periodic review, effectiveness and relevance of the curriculum at all levels to meet the needs of society and the world of work". Where the goals of Nigerian's education undergo periodic review, the education providers should have dictated what works and remove the ones not working as well as improve on the ones working because life is not static rather dynamic. Education is for knowledge impartation as to develop the individual and the nation as a whole.

\section{Relevant curriculum with emancipating goal}

The curriculum should teach self-confidence, innate abilities, history, ethical and moral values and skills with which the beneficiary can take life's challenges. 
From crèche to tertiary level appropriate investment should be made in skill acquisition. Education should make the beneficiary self reliant, this self relevant leads to self development. Education should instill character. It must contain moral values for it to be functional. Education is national investment for the current and future growth of the nation.

Onyenachi and Onyekwodiri [6] (2016) maintain that curriculum is a tool designed for educating a person in order to positively change the orientation, behavior, action and values of that person whose concern is not only to develop self but also the world around him. Okoro and Afurobi [7] (2011) see relevant curriculum as fulfilling what they call triplication of education.

These are: individualization, localization and globalization. This means "our curriculum must be based on local values, suitable global knowledge and technology to support the development of the community and individuals as local citizens. The outcome of this curriculum is that we will develop a local person with national and global outlook. Relevant curriculum endows its learners with appropriate knowledge, skill and attitudes which should enable them harness resources (materials and human) in order to improve the quality of life and the environment.

Ojo [8] (2017) in a workshop for capacity building for industrialization expresses concern about the widening gap and mismatch between the quality of graduates and the actual needs of industries. There is need for training of teachers and laboratory technicians because they impact knowledge to students. Ojo says "Government is worried by the inability of many students to fit into work places because they lack the necessary soft skills required for them to perform". According to him:

As the percentage of unemployed graduates increase yearly, the issue of mismatch between what is offered in institution of learning and the labor market is yet to be addressed. The inadequate capacity building for teachers is acknowledged as a major factor responsible for declining quality.

Ocheja [9] (2017) says there is need to identity the mismatch and develop a national plan for continuous professional development of teachers and laboratory technicians. He notes with dismay that unlike the advanced countries such as Singapore, Nigeria has no approved Continuous Professional Development (CPD), even though it is recommended that all serving teacher should undergo at least 100 hours CPD each year.

Ocheja identified some of the causes of skill gap to be:

- Obsolete equipment;

- Students' teacher ratio;

- Poor quality teaching.

Students eventually graduate with deficiency in critical areas such as communication, technical competence and analytical skills for problem solving.

Ekeh [10] (2007) asserts that education provides the tools with which people are empowered to tackle the problems that face their society. Uwameiye and 
Aduwa-Ogiegbaen [11] (2006) also opine that a worthwhile and sound education should not only meet the challenges of today but also future challenges as well as contribute to creating a future society and its culture.

Library and information science education emancipates mind through reading

Books can take a person all over the world a library card will take you further than a driver's license (Martinez in Maxwell, [12] 2007).

One cannot be a librarian without being a reader. A cook is the first partaker of the food he/she cooks. It is odd for a cook to serve food he/she can't vouch for the taste and nutritional value. Librarian acquires, processes and disseminates information to empower people for life usefulness/development. He/she must convince the information seeker of the worth of the information he/she is serving.

Maxwell [13] (2009) reports of question he asked a group of youth who were in their thirties: "if you could do one thing to change the world, what would it be?" Most of them stated lofty goals. One of them asked Maxwell "so what would you do" Maxwell replied "I'd teach every child in the world to read. I believe the ability to read can open the door to all other learning and personal growth". Reading changes a man for the best.

Excerpt from Maxwell (2007) reports about Reuben Martinez and reading:

What does a boy like Reuben Martinez do in place like Miami, Arizona? Miami is a small mining town of two thousand people in the southeastern part of Arizona that has changed little since its founding in 1907. When Rueben was growing up in 1940s and 1950s most of the town's jobs came from the copper mining industry as they still do. Reuben's parents, who were Mexican immigrants, worked in the mines.

There wasn't much to do in Miami. But Reuben had a curious mind and he found his passion in book-not necessarily an easy task when your parents aren't big readers and your town is so small that it doesn't even have a public library. "My mother always wanted me to put down my books and clean the yard", recalls Reuben, "so I would hide in the outhouse and read because no one would bother me there".

The child was so desperate for reading materials that he became very industrious. "Every morning at 6:45 am, "the newspaper boy would deliver the newspaper and when it hit my neighbor's side of the house, I would wake up, go out the back door, lean against my neighbor's house and read the newspaper every morning thoroughly. Then I'd fold that newspaper and put it back as neatly as I could".

Eventually Reuben got caught. But his neighbor didn't mind and encouraged him to keep reading. Reuben was also inspired and assisted by two of his teachers. They continually encouraged his love of reading and loaned him books. At seventeen, Reuben moved to Los Angeles to find greater opportunities. After several unsatisfactory jobs he saw an ad for a barber college, and he was captivated by the idea of attending. In the 1970s, Reuben Martinez opened his own 
barbershop and became his own boss. He never lost his passions for reading, a passion he wanted to pass on to others, especially young people in the Hispanic and Latino communities. According to a national Endowment for the Arts survey, the reading level among Hispanic is half that of non-Hispanic whites". Martinez wanted to change that. He started out by lending volumes from his two hundred book collection to people waiting for a haircut. The books ranged from Spanish language masterpieces like One Hundred years of Gabriel Garcia Marques and Don Quixote by Cervantes, to American books by Hemingway or Silverstein translated into Spanish, to a singed autobiography by actor Anthony Quinn. He became an advocate for literacy. He talked to parents about reading to their children. He talked to young people diving into books. He tells parents, "Do you want your child to be ahead of the line or at the back of the line, moms and dads? You have to support, endorse, and read to your kid ... If you do that, your kid will be at the head of the line ... and be someone special in this world. Reading does it." And he started speaking at schools and to other groups to promote literacy. He advises his audiences to read twenty minutes a day so that they consume one million words a year. One of his favorite sayings is that books can take a person all over the world a library card will take you further than a driver's license. "I started reading at a very, very young age", says Martinez "and I still do. I read a lot every day. I look forward to that. I love literature".

\section{Library and Information Science: a discipline with entrepreneurship acumen}

Ekong and Williams [14] (2006) view entrepreneurship as acquisition of practical knowledge and skills which are imparted simultaneously for sustenance, self-employment and self-reliance. Eberechukwu in Onyeachu [15] (2011), defines entrepreneurship as that which involves empowering individuals to be self employed and independent Ariteshoma and Mohainmed [16] (2010) say entrepreneurship refers to an individual's ability to turn ideas into action.

From the above definitions one can define entrepreneurship as knowledge application for self sustenance and relevance in the community. The entrepreneur does not just sustain his/her wellbeing, whatever he sets up benefits others because one cannot be jack of all trade. An entrepreneur's small or large scale set up employs hands to work. An entrepreneur therefore is a job creator that is an employer of labor.

According to Onyeachu (2011) entrepreneurship education can be viewed as a process of teaching people how to acquire skills through their discipline and how to utilize these skills for self-sustenance and self-reliance. Entrepreneurship education will help the learner to achieve the well cherished desire which is transition from school to work to earn a living.

Government/non government employment should not be the only hope of an educated person for survival. Essence of education is to empower one with knowledge for survival/development. Popular axiom is that knowledge is power. After being empowered through education and one is still going cup at hand agitating over what government or an organization has not offered him/her for 
sustenance, the knowledge gained becomes questionable.

Onyeachu [17] (2009) emphatically remarked that Nigeria education system requires education that will be filled with skills. Onyeachu further asserts that; bringing entrepreneurship in education in general and in tertiary education in particular is a way of putting our educational system on the desired pedestal of efficiency and functionality to meet the challenges of National needs and Global competitiveness in the $21^{\text {st }}$ century. Uwameije and Aduwa-Ogiegbeam (2006) agree that such education will include nurturing in young people those personal attributes that form the basis of entrepreneurship such as creativity, spirit of initiative, responsibility, capacity of confronting risks and independence. Through these teaching becomes active way of learning instead of simply absorbing knowledge. This means that when learners learn activity, they will acquire appropriate skills and competences which will enable them to be self-reliant and contribute to the development of the society. By educating the individual he/she is equipped with enabling skills to live peacefully and productively in a dynamic society.

Parents and students take pride in getting their children enroll for professional courses in tertiary institution which will enable them on graduation either get worthy employment quick or be self employed. Most of them utilize the tertiary education knowledge to be employed as well as establish private set ups which they manage. Example of disciplines they sought for are: Medicine, Law and Engineering.

Few know that Library and Information Science is a pearl which only the wise discovers, sells all he/she has and buys it. Such people know that pearl turns one to not just wealth owner but wealth creator.

The entrepreneurship empowerment through Library and Information Science (LIS) will give you pride of place better than any other acclaimed professional course. An involvement convinces.

\section{Entrepreneurial nature of the Library and Information Science courses}

The current curricula for Nigerian education fully incorporate entrepreneurship. This is to make the citizens self reliant which is among the goals of Nigerian policy on education. Education which is a sure and quick way of knowledge transfer and development to individuals and society is the best gateway to lead the citizens through entrepreneurship (Onyenachi and Akidi [18] 2015). Rather than have a fixation of looking for jobs, there is option to actually set up one's own business on graduation. Entrepreneurship makes Library and Information Science graduate become self employed as well as an employer of labour. $21^{\text {st }}$ century librarians are innovators who explore new technologies and noble ideas in the relentless pursuit of excellence and embracing the entrepreneurial culture.

According to Onyenachi and Akidi (2015) entrepreneurial librarianship involves creative thinking, strategic planning, targeted market, innovation and at times, risk taking. Entrepreneurship in education focuses on making the student see how what they are learning prepares them for life in the real world (Etim, 
[19] 2015). She maintains that "entrepreneurship education should be multi-disciplinary in nature in order to provide the learner the diverse experiences needed to succeed in the contemporary business environment”. In line to Etim's view on entrepreneurship education, the multi disciplinary nature of library and information science has inherent advantages. The products are equipped for either being employed or self employed on graduation.

Taking Library and Information Science programme in Michael Okpara University of Agriculture Umudike as instance, because of the exposure which the students have in entrepreneurial courses and the expertise they acquire they are imbued with the competence to succeed as entrepreneurs and "inforpreneurs" in agriculture. Other entrepreneurial courses of Library and Information Science (LIS) include printing/publishing, library consultancy, binding, paper recycling, book trade/stationary business, production and marketing of library equipment etc.

Etim (2015), maintains that entrepreneurship opportunity in Library and Information Science (LIS) profession is any occasion in which products and services are tendered by means of new discovery or by virtue of innovation that culminate in transforming the landscape of Library and Information Science services.

\section{Conclusion}

Bible says woo unto anyone who puts his trust in man. Bible cannot be broken, woo (restiveness) actually becomes the portion of those putting their trust in man (government). For the individual looking unto government for survival where such is not forth coming or what is offered, is considered unsatisfactory restiveness occurs. With focused Library and Information Science education for self-reliance, the graduate has no business with restiveness. It is a professional course that trains the graduate not to be dependently looking unto man (government) over what to offer them. Through the discipline, positive change becomes much more enhanced and easier to achieve. Library and Information Science education makes clearer the roles, importance and place of libraries and information centers for solution to societal issues and the mind is emancipated and properly guided for better value other than restiveness. With this national development, unity is achievable. The entrepreneurial opportunities in Library and Information Science create no dull moment. The knowledge acquired sets one on the worthy course of life for self and society development and unity.

\section{References}

[1] Cawthra, M. (2011) Collusion and Criminalisation: Fuel Conflict in the Niger Delta. Conflict Trends, No. 2, Accord.

[2] Jike, V. (2010) Oil Companies and Host Community: A Probable Scenario for Reciprocal Empowerment. Journal of Human Ecology, 30, 131-142. https://doi.org/10.1080/09709274.2010.11906282

[3] Idumudia, U. and Ite, U. (2006) Demystifying the Niger Delta Conflict towards and 
Integrated Explanation. Review of African Political Economy, 109, 391-406. https://doi.org/10.1080/03056240601000762

[4] Kachikwu, I. (2017) Those Who Keep the Peace Will Be Rewarded. 25.

[5] Federal Republic of Nigeria (2013) National Policy on Education. $6^{\text {th }}$ Edition, NERDC Press, Abuja.

[6] Onyenachi, J.C. and Onyekwodiri, N.E. (2016) Provision of Quality Resources for Quality Library and Information Science Education: An Indispensable Mandate. In Quality Assurance in Library and Information Science Education in Nigeria. Proceedings of the Annual National Conference of NALISE, 9-13 May 2016, University of Ibadan, 15-20.

[7] Okoro, F. and Afurobi, A.O. (2011) Relevant Curriculum for Refocusing Education in Nigeria in the $21^{\text {st }}$ Century. In: Egbule, P., Tsbotndip, J.E. and Aboho, D.A. Eds., Refocusing Education in Nigeria in the $21^{\text {st }}$ Century, 175-188.

[8] Ojo, J. (2017) F.G Takes Steps towards Eliminating Skills Gap in Education. 33.

[9] Ocheja, E. (2017) F.G. Takes Steps towards Elevating Skills Gap in Education. 37.

[10] Ekeh, S.L. (2007) Riding on ICT to Exit Recession the Guardian. 42.

[11] Uwameiye, R. and Aduwa-Ogiegdaen, S.E. (2006) Developing Entrepreneurship Culture among Young People in Nigeria. Journal of Curriculum Organization of Nigeria CON, 13, 97-103.

[12] Maxwell, J.C. (2007) Talent Is Never Enough. Thomas Nelson, Nashville, 31-35.

[13] Maxwell, J.C. (2009) Put Your Dream to the Test. Thomas Nelson, Nashville, 93.

[14] Ekong, A.O. and Williams, P.S. (2006) Entrepreneurship Education in Nigeria and Its Implication for Manpower Needs of the Nation. Nigerian Journal of Professional Teachers, I, 112-120.

[15] Onyeachu, J.A.E. (2011) Refocusing Tertiary Education in Nigeria towards Entrepreneurship Education: Challenges for the Tertiary First Century. In: Egbule, P., Tabotndip, J.E. and Aboho, D.A., Eds., Refocusing Education in Nigeria in the $21^{\text {st }}$ Century, West and Solomon Publishing Co. Ltd., Kano, 78-95.

[16] Aristhoma, O.M. and Mohainmed, A.M. (2010) Entrepreneurship Training as an Instrument for Achieving Economic Growth in Nigeria. Knowledge Review Multidisclinary Journal, 21, 117-123.

[17] Onyeachu, J.A.E. (2009) Education for Skill Acquisition: A Focus on Adult and Non-Formal Education in Nigeria. Journal of Qualitative Education, 6, 34-40.

[18] Onyenachi, J.C. and Akidi, J.O. (2015) Entrepreneurial Librarianship: Need for Information Brokerage. Jewel Journal of Librarianship, 8, 96-105.

[19] Etim, F.E. (2015) Repositioning Library and Information (LIS) Graduates in Nigeria for Self Employment through Entrepreneurship Educates. National Association of Library and Information Science Educators in University of Uyo, Nigeria, 1-16. 